\title{
DEVELOPMENT OF MUNICIPAL WASTE MANAGEMENT
}

\author{
Inara Teibe \\ Department of Environmental Management \\ Faculty of Economics and Management, University of Latvia \\ 19 Raina blv., Riga, 1586, Latvia \\ Ph.: +(371) 67034572, e-mail: inara.teibe@inbox.lv
}

\begin{abstract}
This paper is based on an empirical work done by author on a series of case studies such us document studies and analyzing the best practices examples. The objective of this research is to find out barriers to reach regional waste management plan demands in three municipalities: Salacgriva, Saulkrasti and Ikskile. Author gives proposal with some recommendations for development of municipal waste management as well. There are several views and attitudes of local stakeholders such us municipality, waste producers, waste collectors and mediators on how to manage collection and transportation of solid waste in practice as well as on public involvement in the process. Passivity of stakeholders to realize theirs needs and requirements mainly depend on the limited human and financial resources, but often political will, skepticism or lack of knowledge. A lot of problems could be solved faster and easier, if there existed better communication and collaboration among local stakeholders.
\end{abstract}

Keywords: municipality, sustainable waste management, stakeholder's collaboration.

\section{Introduction}

Recycling of the waste is being seen as a solution of European Commission to Member States on how to solve problems with the significant increase waste amounts. This approach is preferred mainly, because of the huge costs involved in waste landfill as well as their irreclaimable impacts to environment and the fear of society about unknown impacts on people's health. Essential issues are also the reduction of human consumption and protection of natural resources by reusing and recycling of waste and using it as raw material. Reusing and recycling activities have an important role in the developed countries, because it creates large part of their work place share, reduce price of raw materials and necessity to import them and it is an effective way to realize environmental protection (Marion, 2002).

European Union Landfill Directive sets targets for all Member States on reduction of waste arising and development of waste recycling and recovery as well encourages use of recycling materials and renewable energy, to meet nature protection requirement and to prevent wasteful use of land (Directive 1999/31/EK).

At an average from EU27 Member States only $40 \%$ of municipal waste are recycled or composted in 2008 and there are big differences among each state's environmental performance in practice. For example, in Germany and Netherlands municipal waste was landfilled only $1 \%$ from total amount; Sweden and Austria - 3\% to compare with Estonia $75 \%$, Latvia $-93 \%$ and Lithuania- 96\%. In its turn, in Bulgaria activities of recycling taken as whole was very insignificant and almost all collected municipal waste was landfilled (CEWEP, 2010 (11)).

The amount of municipal waste generated and landfilled in $\mathrm{kg}$ per person varies significantly across Member States also. This variation is mainly due to different consumption behavior. If we compare Structural Indicator in previous mentioned countries then municipal waste generated and landfilled (kg per capita) are the following: Germany $587 \mathrm{~kg}$ per capita and 2 kg per capita; Netherlands - 616 and 4; Sweden - 485 and 7, Austria - 591 and 4, Estonia 346 and 214, Latvia - 333 and 307, Lithuania - 360 and 326, Bulgaria - 468 and 450 (Eurostat 2010). Of course, such high public activity and participation in waste sorting and recycling 
can be achieved also with strong waste management policy and high landfill taxes, for example, Sweden has landfill taxes 110-160 euro per tonne, Austria 60-130, Netherlands from 16, 79 for non- hazardous up to 107.79 for hazardous waste, Lithuania 14, 5 (CEWEP, 2010 (9)) and Latvia 25 -35 euro per tonne (Landfills: Daibe, Getlinii, Kivites webpages).

Partly thanks to impact of day's economical situation, which has contributed to reduction of the average of household consumption expenditure (total in money and in kind) of inhabitants of Latvia (average per household member monthly, LVL) from 232.06 LVL in 2008 to 195.27 LVL in 2009 (CSP) as well as historical traditions of composting the biological waste in their private territory, inhabitants of Latvia are often making so comparably low amount of produced waste per one person. However this indicator and inhabitant's density of Latvia in average 34.6 persons per $\mathrm{km}^{2}$ in 2010 (CSP) shows, that in Latvia it will be very hard to realize energy recovery from municipal waste or it will be very expensive for local inhabitants, therefore the only cost - effective way how to reduce waste in landfill is recycling, reuse and composting.

The main waste management regulations applying setting waste management priorities in Latvia are Directive 2008/98/EC European Parliament and of the Council (19.11.2008) on waste and repealing certain Directives, National Waste management plan from 2006 to 2012 (29.12.2005) and Law On Waste Management (18.11.2010), which are setting major principles of sustainable waste management as follows 1) to minimize waste generation; 2) to maximize waste recycling and reuse; 3 ) to ensure the safe and environmentally sound disposal of waste.

The formulation of goals and priorities, determination of roles and jurisdiction, and the legal and regulatory policy framework determinate basely demands for waste management system and responsibility of municipality, however it do not give direct advice, how to achieve effective waste management, sustainable development and successful collaboration among stakeholders in local municipality depending on existing situation.

In practice there exist different views and attitudes of stakeholders on how to organize waste management. There are mainly two groups: passive, who have been felling comfortable in the existing situation and they do not see any need for change and formally waste management is provided; and active, who have been involved in public education on development of sustainable waste management in line with demands and rules of European Union and National level.

\section{Materials and methods}

This research has focused on problems of small municipality waste management with number of 10000 inhabitants. After the new administrative-territorial reform in 2008 in Latvia there are at least 70 municipalities of this size (www.raplm.gov.lv). The empirical work was made in three small municipalities: Salacgriva, Saulkrasti and Ikskile and major attention was paid to sustainable waste management implementation.

This paper included brief summary of following studies:

1) Individual case study research (Teibe, 2010 b), "Waste management research for Ikskile municipality, 2010", based on document studies, 16 interviews, 205 responds to questionnaire and individual observations;

2) Case studies (Teibe, 2010 d; 2010 c), Teibe I., Ozola G., Sturma A., Jakusenoka S. "Climate change adaptation policy planning guidelines for coastal municipality: Salacgrivas municipality. Nature environment sector" (2010 April-June), based on document studies, 18 interviews, 16 responds to questionnaire, individual and group observations; and Teibe I., Kirsona I., Ozola G. "Environmental communication action program guidelines for coastal municipality: Saulkrastu municipality. Household management sector" (2010 October -2011 January), based on document studies, 21 interviews, 93 responds to questionnaire, individual and group observations; 
3) Individual case study (Teibe, 2010 a) "Environmental communication in waste management: inter - municipal partnership case", North Vidzeme Waste Management organization (ZAAO) - best practice example.

Waste management research focused on accessibility and effectiveness of provided services and infrastructure, inhabitant's willingness to participate and local shareholders (such municipal authorities, waste collector and transporter, waste producer and mediator) estimation of activities (Fig.1).

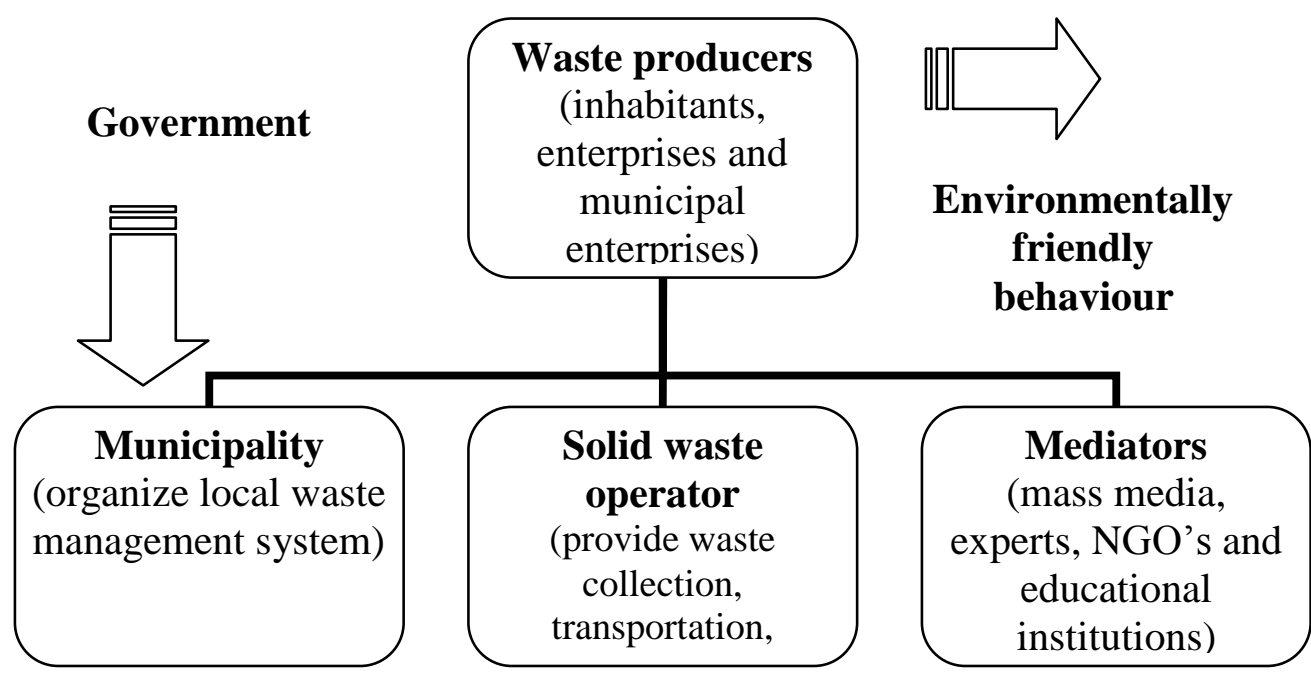

Fig.1. Local stakeholders of waste management

\section{Results}

Saulkrasti and Salacgriva are coastal municipalities. After administrative-territorial division municipality of Salacgriva consist to North Vidzeme's region, but municipalities of Saulkrasti and Ikskile belong to Pieriga's region.

Characterization of municipalities territorial in 2010:

1) Municipality of Salacgriva: total population 9522 , total land area $63,6 \mathrm{~km}^{2}$, population density 15 pers per $\mathrm{km}^{2}$, defined 1 territorial area, where has been operating 1 solid waste operator;

2) Municipality of Ikskile: total population 9125 , total land area $132,1 \mathrm{~km}^{2}$, population density 69 pers per $\mathrm{km}^{2}$, also defined 1 territorial area, where have been operating 3 solid waste operators in the full market competition;

3) Municipality of Saulkrasti: total population 6243 , total land area $47,7 \mathrm{~km}^{2}$, population density 131 pers per $\mathrm{km}^{2}$, in common with municipality of Ikskile, here defined 1 territorial area where have been operating 3 solid waste operators. One of the specific problems of municipality of Saulkrasti is that the amount of population increases from 3 till 5 times during the season. (May-October) (Information from municipality).

The process of waste management in these municipalities is being determined by local governments and local rules on waste management. According to these rules in whole territory there is determined order of waste management, administrative area division of solid waste management zones, requirements for waste collection, transport, handling and storage, as well as the procedures of the payments for the services.

The rule is binding for all persons in the administrative territory, who are performing regulated activities according to the conditions. The administrative responsibility in case violations also mentioned here.

Municipality of Salacgriva is participating in ZAAO. The main purpose to establish the pilot project ZAAO in the Northern part of Vidzeme of Latvia in 1998, was to remove the existing 104 legal and illegal dumpsites which were non - conformed with European Union and 
National requirements as well as create a new, modern municipal solid waste landfill and introduce waste management system, which would cover Cesis, Limbazu, Valka and Valmiera districts. This territory was chosen mainly because here is situated National Park Gauja and the Biosphere Reserve of Northern Vidzeme, which require special environmental protection.

Today ZAAO is a largest full services waste operator in North Vidzeme region and the board is operated by 22 municipalities: Valmiera city and 21 counties, including municipality of Salacgriva.

When organisation ZAAO was established, every municipality participated with local investments in the organization share capital and entrusted centralize to ZAAO make and develop to local waste management system as well as provide educational activities. Today ZAAO can be considered as best practice in waste management in Latvia.

In the Pieriga's region there does not exist organization like ZAAO, therefore municipalities of Ikskile and Saulkrasti are organizing waste management depending on available human and financial resources, their understanding on how the wast management process should be organized according to National regulation on waste management.

\section{Municipalities}

In all municipalities, which have participated in empirical work, they have their own enterprise, which organizes municipal solid waste collection from all enterprises and households of municipality as well as public territories like parks, streets, graveyards etc. This company also must sign a contract with solid waste operator, which wants to provide collection and transporting services in this territory in accordance with law regulating public purchases and legislative demands and criteria from the municipal authority.

Every private household or waste producer according to local waste management regulation has to sign contract directly with solid waste operator ZAAO, in the municipality of Salacgriva, however, in the municipalities of Saulkrasti and Ikskile waste producers can choose the company among 3 operators, which will provide waste collection. In practice here even in one territory, street or private apartments house, municipal waste collection are providing all 3 operators. Here, the selection of operator is based on principle of full market competition: better price for the service, comfort of service application, offered services or company image.

In order to organize unsorted and recycled solid waste collection and transportation in the whole territory, municipality takes for the basis the knowledge about average amount of waste, which gives only a rough idea of waste generation, composition and types (LASA, 2007). But in practice no one of the three municipalities was able to actively monitor the amount of waste, therefore it was forcible to receive this information only from waste operators.

If to describe a total amount of collected waste in municipalities, (Fig.2), even though municipalities of Salacgriva and Ikskile are territories with quite similar number of inhabitants, respectively 9522 and 9125 , here is significant difference between collected waste amounts. One of the reasons is population density (look before mentioned features of municipalities), in municipality of Salacgriva more pronounced private houses and separate located households, but in municipality of Ikskile a large part of population is living in apartment houses.

Second reason is that produced waste amount was determined also by average income level in the family, as municipality of Ikskile belongs to Pieriga region, where according to data of Central Statistical Bureau in 2009 "Consumption expenditure average per household member per month" was higher 230.57 LVL per person than in Vidzeme's region - 182,62 LVL per person (CSP). 
And the third one, the collected waste amount is directly affected by the applied accounting method, as vehicles of solid waste operator of municipality of Salacgriva are weighted before landfill the data is more precise if compared to the municipality of Ikskile where largest part of the collected waste is calculated from contracts and the allowable mistake is aproximally $+/-20 \%$ (waste operator information).

\section{Solid waste operators}

Each operator's tariffs of solid waste collecting and transporting by region are approved at the Public Utilities Commission, which is an independent state institution responsible for regulation of energy, telecommunications, post and railway sectors in accordance with the law On Regulators of Public Utilities and the corresponding normative acts in the regulated sectors. This information is open to public and review at website: http://www.sprk.gov.lv. Depending from each administrative territory distance from landfill Daibe, where are disposed all collected municipal solid waste in North Vidzeme, ZAAO have a variable transport rates confirmed by each municipality.

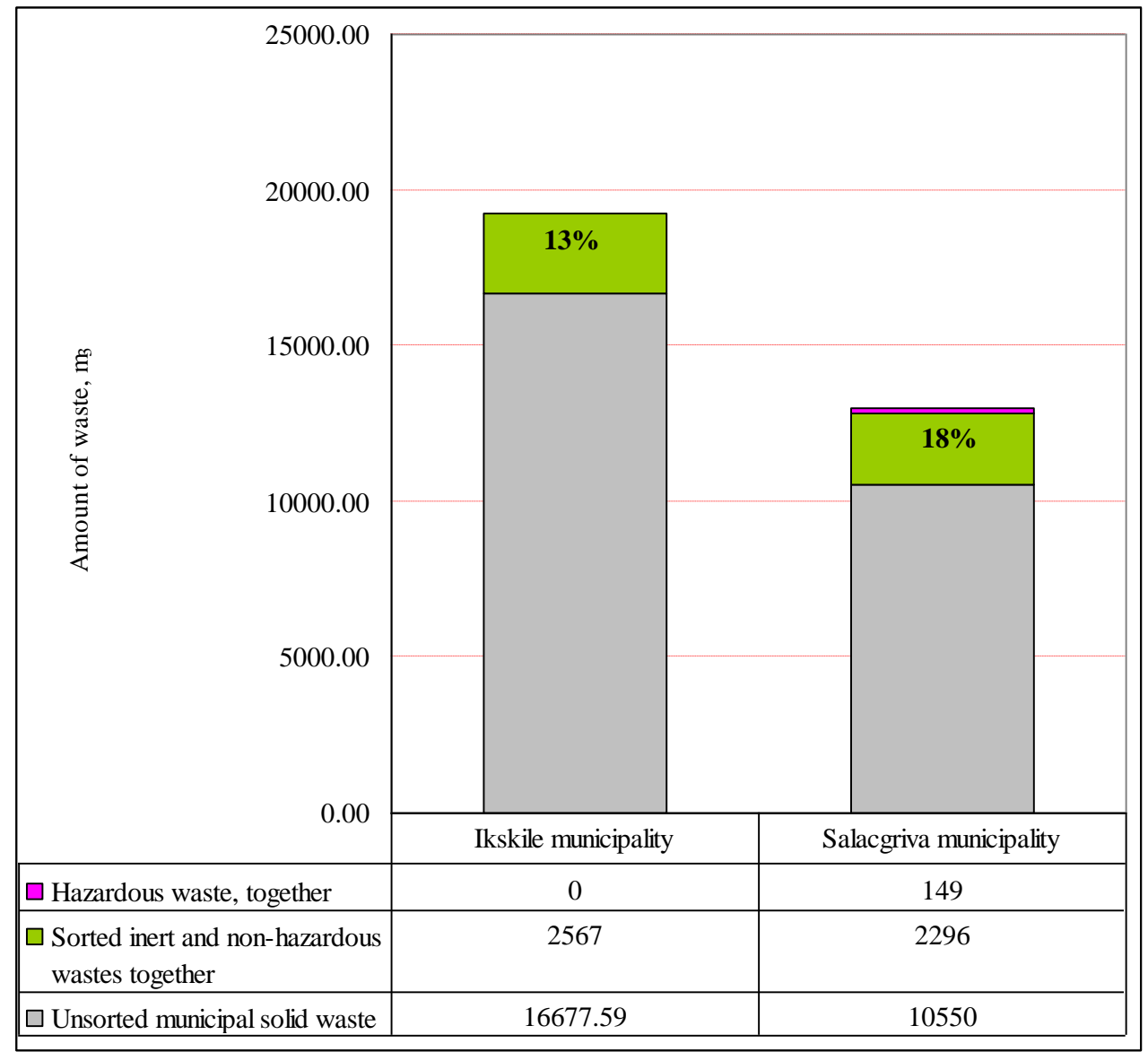

Fig.2. Collected municipal waste in total: Ikskile and Salacgriva municipalities in 2009

The municipality in cooperation with waste operator is organizing separate collection of municipal waste, including hazardous waste of households, in whole administrative territory under the National Waste Management Plan and Regional Plans (Law on Waste Management, 18.11.2010).

During the reporting period in 2009 in the municipality of Salacgriva were available 10 on street recycling EKO points for PET packaging, glass and paper in the different residential areas and 1 recycling EKO area for 12 different fractions in town according to tasks mentioned by ZAAO (North Vidzeme Regional Waste Management Plan from 2006 till 
2013). Each household can additionally purchase EKO bag for PET packaging, paper, metal and PE plastic sorting at their own territory and once per month to deliver over ZAAO or deliver by self to recycling EKO point or EKO area.

But from municipality of Ikskile part, there are 6 recycling points for PET packaging, glass and paper in mostly located in the town, multi apartment houses courtyards. For the present waste recycling area are still being arranged, therefore residents can bring their own vehicles to the other cities recycling areas if case the waste fraction can not pass recycling points. This is observed also on Figure 2 in total amount of collected municipal waste, such as lack of information about hazardous waste of households in municipality of Ikskile.

Municipal waste recycling is very weakly developed in municipality of Saulkrasti, mostly because here was very poor involvement in local waste management of cottager in the horticultural cooperatives. Due to irresponsible behavior of cottagers in the recycling points were receiving very poor quality materials, therefore waste sorting was suspended. However some pilot projects municipality had made again in the last season, such as recycling points for PET packaging in seacoast and had got a very good result.

The proportion of local municipalities of Ikskile and Salacgriva collected waste being recycled, composted or reused is shown in the $3^{\text {rd }}$ Figure.

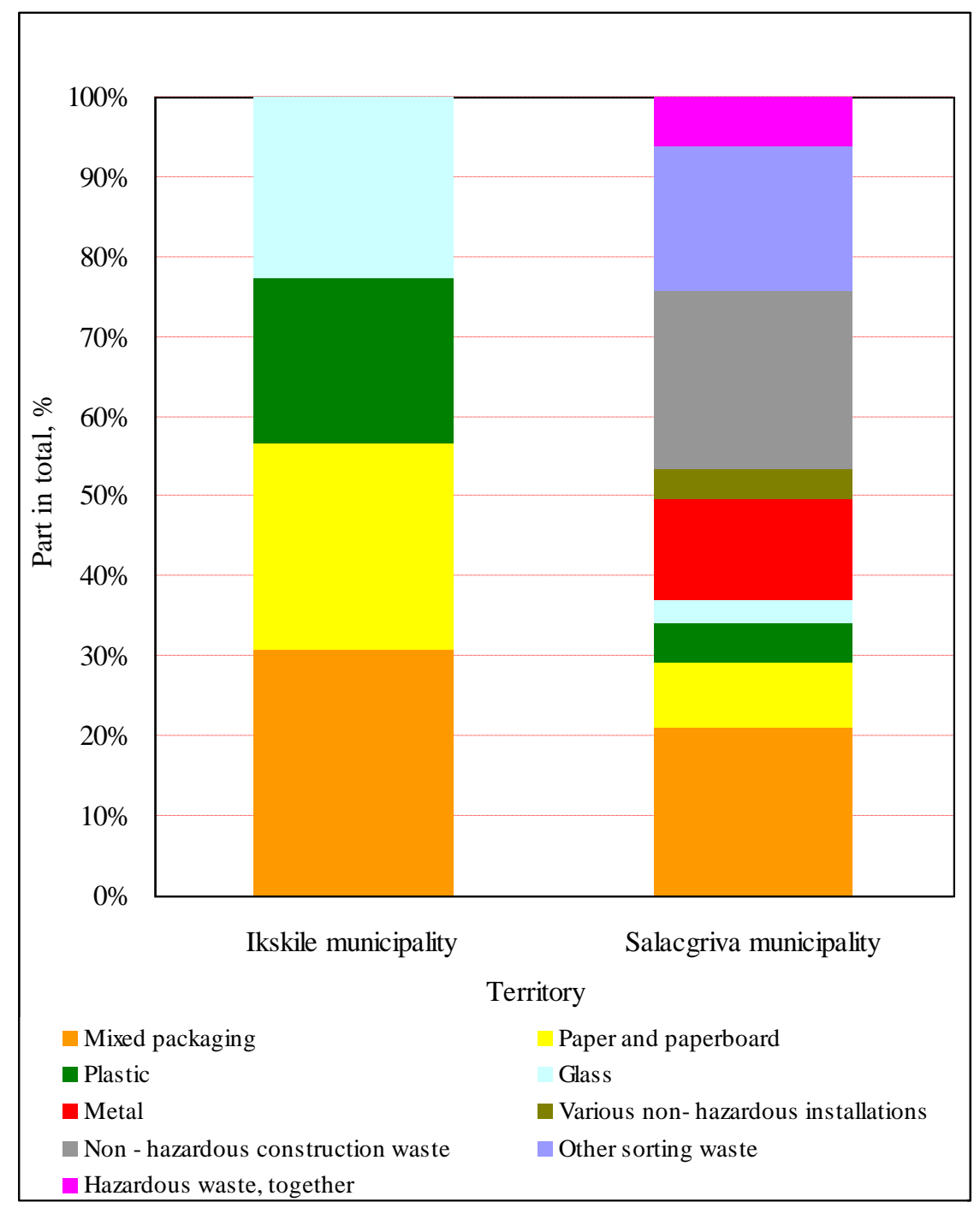

Fig.3. Separate collected waste by fraction: Ikskile and Salacgriva municipalities in 2009 
These data evidence that the more possibilities of recycling are provided in the territory, the better information can be collected about municipal produced waste composition and quantity.

\section{Waste producers}

Within Empirical work in the municipalities of Ikskile and Saulkrasti was carried out sociological research to find out, what kind of waste management services inhabitants more often are using, data shown in Figure 4.

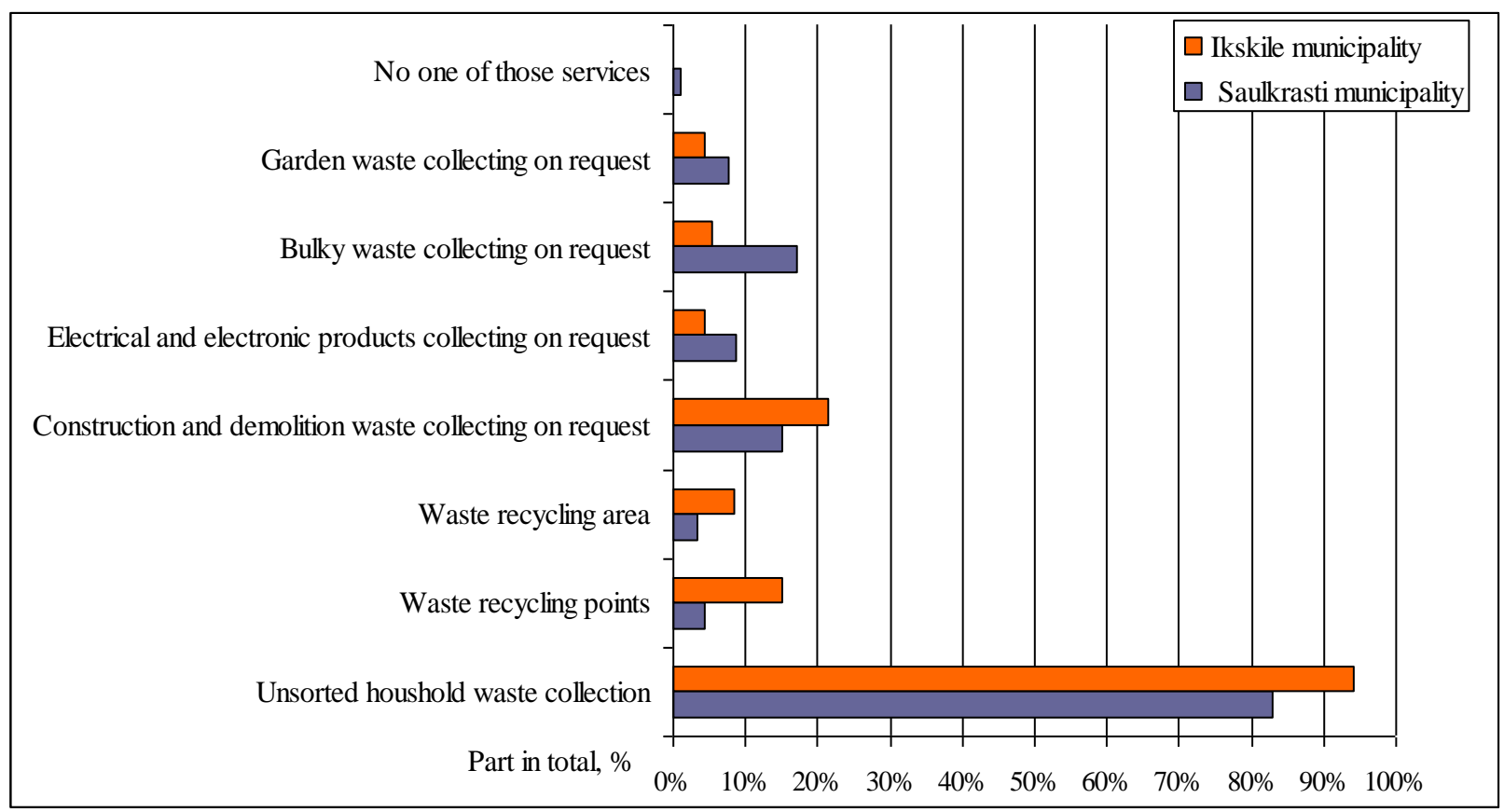

Fig.4. Public partnership: Ikskile and Saulkrasti municipalities

Respondents were indicated that the most commonly requested is the unsorted household solid waste collecting. Results indicate that there is very weak public participation in municipal waste recycling. From all respondents only $15 \%$ from Ikskile and 5\% from Saulkrasti are using local recycling points, much less than $8 \%$ are ready to deliver the sorted waste to recycling areas in the other cities.

Residents in both municipalities have been more active in delivering of bulky and construction waste collecting on request, however green garden waste separation of the total waste stream has not gained popularity.

According to the results of sociological research the inhabitants gave an explication, why they have lack of motivation, mostly because they have not enough information about possibility and places where to bring recycling waste, quite often these containers had not been collected regularly or had been thrown together in to the same vehicle - sometimes together with unsorted municipal waste.

According to European Union Landfill Directive 1999/31/EK all Member States have to organize activities to reduce methane emissions from landfills due to the biological degradation of the many types of organic materials. Member States must put an effort to reduce greenhouse gasses, encouraging projects that turn the landfill gases into electricity as well as regularly controlling these emissions.

Therefore each country and local municipality should take measures and promote separate collection of biodegradable waste, such us sorting, recovery and recycling, but meanwhile local municipalities are not following these demands. In the best case residents have the possibility to deliver garden waste (leaves, grass cuttings and fruit) into composting area of 
municipality or hand over to waste operator like ZAAO by less tariff such unsorted waste. In their turn the collection and transportation of the kitchen waste from households and public catering places was very hardly assured in the visited municipalities.

\section{Mediators}

Environmental communication and education in the waste management sector is mainly provided by two companies: "Latvijas Zalais punkts" since 2000 and "Zala josta" since 2002. These are producers' responsibility systems in Latvia that deals with the implementation and coordination of the system for managing packaging waste and disposable tableware and cutlery, as well as waste electric and electronic equipment and goods harmful to the environment. Since 2005 there is established waste management coordinator "Zalais centrs" as well, but this company is responsibility only for environmentally harmful products disposal.

Companies "Latvijas Zalais punkts" and "Zala josta" have their own educational programs for public, for example "Latvijas Zalais punkts" has the "Green Dot School" program with an objective to increase the knowledge on ecological issues and to strengthen the sense of responsibility for the environment, promoting environmentally friendly life-style. This program has various educational framework and methods for children, schoolchild and students and any educational institution can participate here, only themselves must take the initiative to apply.

Basically local solid waste operators, which are dealing with waste collecting in the municipalities of Ikskile and Saulkrasti are quite passive educators, mainly due to competition. No one is ready to invest money and to provide service awareness or to realize some educational activities. Environmental communication from these companies is more like than campaign for collecting exactly one type of waste.

Within its capabilities in local municipalities are running formal and informal educators and institutions. For example, in municipality of Saulkrasti very active children are involved in Nature club in the primary school of Zvejniekciems, also in the local library there is available a small collection of literature on environmental issues, occasionally environment-related activities were also provided in the secondary school of Ikskile. Mainly with environmental education in these municipalities are operating enthusiasts or non-governmental organizations that care about the environment. However activities are not coordinated and have weak collaboration with other local interest groups and often with limited budget. But during the research there have been noted also the positive trends - more and more environmental projects are financed by local municipality.

The best practice example in the waste management sector in Latvia is ZAAO, which has done a significant investment in public involvement in environmental education since 2001. As an effective environmental communication instrument in ZAAO they are successfully using all four components: dissemination of environmental information, environmental education, public participation and collaboration and environmental friendly behavior (Ernsteins 2003).

In order to realize modern and environmentally friendly waste management systems and minimize the possible contamination into the environment, ZAAO is collaborating with four defined target groups: municipality, customers, society and educational institutions. Keeping in mind the defined target groups" needs, requirement and specific characteristic, environmental education and awareness activities, content and methods are developed. According to this model ZAAO is organizing environmental education in the waste management sector all over the North part of Vidzeme. All municipalities of this region are encouraged to participate and support ZAAO organized activities, which focused on public education, information and participation in protection of environment. 


\section{Discussion}

Results indicate that the responsible local authorities are not very interested to get deep knowledge into the environmental field, including waste management, although their understanding is necessary to build sustainable development of the municipality. Municipalities had inadequate information about real estates and inhabitants and have not monitored the involvement of local citizens in the waste management system. And basically it is not possible to assess how effectively system is working and manage it. The municipalities of Ikskile and Saulkrasti had not estimated types and quantities of municipal waste according to their producers, therefore it is hard to find out what kind of investments would be needed in order to attract funding for development of the system.

Special attention should be paid to involvement of inhabitants, meaning regular monitoring and administrative controlling, including work with the debtors. Result shows that these issues have not been paid enough attention by local municipalities, leaving the problem solving to waste operators.

One of the indicators that local government should follow to is average generated waste per capita in urban and rural areas. But in practice in such small municipalities have in prevalent only small and medium sizes enterprises, therefore the waste operators have not kept separate records on the amount of waste collected from residents and businesses. However, the random local government would to carry out such inspections, focusing on apartment houses where waste containers are kept in backyards and have publicly available and households where waste collected less than once a month or choose other criteria of inspection.

Such a common position and situation in regions are preventing implementation of regional waste management plan. In the future, these municipalities might be faced with a very expensive unsorted waste disposal costs, since the nearest landfill cells will be quickly filled and the waste disposal options will be limited or will be located quite far from territory. Following such a scenario will increase protest of inhabitants against the high waste collecting tariff and after that will follow illegal dumps in the environment.

\section{Summary}

If the waste management laws, plans and regulations were introduced in municipalities from top to bottom mostly without awareness of each region's waste management situation and problems, except the North Vidzeme region, then in current situation the initiative should come from municipalities, from bottom to top, specifying the investments that would be needed for waste management development in the territory.

The first step in order to develop in municipalities for currently formally on-going waste management is to elaborate local framework of concept and plans. It being understood that the municipality has identified the internal and external resources and the criteria which are necessary for realizing the waste management in accordance with an order priority and as near as possible to waste producers; municipality has sufficient and timely qualitative and quantitative information about waste types, quantities and recycling in the whole territory and the potential of public participation and involvement; municipality fully controls and manages waste collecting and transporting processes within its territory and exercises continuous development of opportunities.

\section{Acknowledgment}

The author is thankful to the municipality of Ikskile for responsiveness to conduct a detailed waste management research in practice, especially to Indra Leja, Head of Development Division, Scientific supervisor Ruta Bendere Dr.Phys, as well as collaboration partners and colleagues from the University of Latvia (supervisor Prof. Raimonds Ernštiens), municipalities of Saulkrasti and Salacgriva and to all representatives from stakeholders for successful cooperation and participation. 


\section{References}

1. Atkritumu apsaimniekošanas likums. LR Saeimas pieņemtais likums, 18.11.2010// laikraksts „Latvijas Vēstnesis", Nr.183 (4375), 17.11.2010.) [stājas spēkā 18.11.2001.] Available at http://www.likumi.lv

2. Audit Scotland "Sustainable waste management", ISBN 978190563475 0, AGS /2007/7, September 2007, 45 p. Available at http:// www.audit - scotland.gov.uk (28.01.2011)

3. Centrāalā statistikas pārvalde (CSP) /Central Statistical Bureau, Available at http://data.csb.gov.lv (04.02.2011)

4. Confederation of European Waste - to- Energy Plants (CEWEP), Recycling and Waste-to- Energy in combination for sustainable waste management, report of November, 2010. Available at http://www.cewep.eu/information/policy/m_554 (15.02.2011)

5. Confederation of European Waste - to- Energy Plants (CEWEP), Lanfill taxes and bans, report F September, 2010. Available at http://www.cewep.eu/information/data/landfill/index.html (15.02.2011)

6. Eiropas Parlamenta un Padomes Direktīva 2006/12/EK ( 2006. gada 5. aprīlis), par atkritumiem //Oficiālais Vēstnesis-2006.- Nr. 114 , 27.apr.- 9 - 21.lpp.

Available at: http://eur-lex.europa.eu/LexUriServ/LexUriServ.do?uri=CELEX:32006L0012:LV:HTML (07.02.2011)

7. Ernsteins R. Environmental communication. Leonardo da Vinci Community Vocational Training Action Programme, Institute for Environmental Science and Management, University of Latvia. 2003.,96.p.

8. Eurostat, Municipal Waste Landfilled, $\mathrm{kg}$ per capital (Structural Indicator). Available at http://epp.eurostat.ec.europa.eu/portal/page/portal/waste/data/wastemanagement/landfill (03.02.2011)

9. Latvijas Atkritumu saimniecības asociācija, „Atkritumu saimniecība”, Rīga, 2007. 132. lpp.

10. Marion S., Coggins C, StovinV., Life cycle assesment and waste management, Volume 4, Istanbul, 2002 $(2317-2324$ p.)

11. Direktīva 1999/31/EK (1999. gada 26. aprīlis) par atkritumu poligoniem. Available at http://eurlex.europa.eu/LexUriServ/LexUriServ.do?uri=CELEX:31999L0031:LV:HTML (15.01.2011)

12. Par atkritumu apsaimniekošanas valsts plānu 2006.-2012.gadam, Ministru kabineta rīkojums Nr.860, 29.12.2005// Laikraksts „Latvijas Vēstnesis” Nr. 210 (3368), 30.12.2005, [stājas spēkā 29.12.2005.] Available at http://www.likumi.lv

13. Par Ziemel̦vidzemes reǵionālo atkritumu apsaimniekošanas plānu 2006.-2013.gadam. Ministru kabineta noteikumi Nr.797, 26.09.2006// Laikraksts „Latvijas Vēstnesis” Nr. 156 (3524), 29.09.2006.) [stājas spēkā 30.09.2006.]. Available at http://www.likumi.lv

14. Sabiedrisko pakalpojumu regulěšanas komisijā (Public Utilities Commission). Available at http://www.sprk.gov.lv/index.php?sadala=480 (06.01.2011)

15. Teibe I. "Vides komunikācijas attīstība atkritumu saimniecības sektorā: pašvaldību un mērķgrupu sadarbība" Rīga, 2010 a, 5.lpp. University of Latvia, Riga.

16. Teibe I. Ikšşiles novada atkritumu saimniecības izpēte 2010, 2010 b, 68.lpp. University of Latvia, Riga.

17. Teibe I., Ķirsona I., Ozola G. "Piekrastes pašvaldības vides komunikācijas rīcības programmas vadlīnijas: Saulkrastu novads, Mājsaimniecības vides pārvaldības sektora izpēte (2010, X -2011,I), 2010 c, 91 p., University of Latvia, Riga.

18. Teibe I., Ozola G., Šturma A., Jakušenoka S. „Klimata pārmaiņu adaptācijas politikas plānošanas vadlīnijas piekrastes pašvaldībai: Salacgrīvas novads. Vides sektors, Rīga, LU, 2010 d, 94 p., University of Latvia, Riga. 